DOI: 10.7592/methis.v13i16.12458

\title{
Värss ja proosa ${ }^{1}$
}

Juri Lotman

Värss (luule, poeetiline kõne) kujutab endast tähendusest eriliselt küllastatud ja spetsiifiliselt korrastatud kõnevormi. Värss realiseerib keele poeetilist funktsiooni. ${ }^{2}$ Ajalooliselt kujunes värss välja järgmisel viisil. Igas kultuuris eristuvad kahte tüüpi sõnumid:

1) need, mis rahuldavad päevakohase informatsiooni vajadusi,

2) need, mis talletuvad kultuurimällu.

Viimastel on esiteks teatav eriline tähendus ning teiseks säilitatakse nad erilisel viisil (raiutakse kivisse, kirjutatakse pärgamendile, hoitakse alal arhiivis või raamatukogus). Kirjaeelses ühiskonnas oli selliseks ühiskondlikuks hoidlaks kollektiivne mälu. Seetõttu loodi eriti tähtsaid, pikaajaliseks säilitamiseks mõeldud tekste nende meelespidamist soodustavas vormis. Siin avaldub värsi seos inimese ja kultuuri mnemooniliste mehhanismidega. Nii kujunes värss erilise kõne liigina ja spetsiifilise tekstigrupina, mis eristub kogu ülejäänud sõnumite massist. Eristumise võis saavutada kas keeleväliste vahendite kasutamisega või keelestruktuuri keerulisemaks muutmisega. Esimene võis avalduda selles, et teatud tekste tuli laulda, esitada retsitatiivselt muusika saatel, varustada spetsiifiliste rütmiliste kehaliigutuste või tantsuga. Arusaam, et värssi lauldakse ja et sellele vastandub „lihtsalt“ kõne ilma muusikalise impulsita, on omane tervele reale kultuuridele ning on tavaline rahvaluules. Ent ajalooliselt valdavaks on osutunud teine tendents, mis seob värsi mõiste kõne täiendava organiseeritusega. See seisneb selles, et keelestruktuuri teatud tasandile lisatakse reeglipäraste korduste organiseeritusega täiendav korrastus, mis ei ole keele(rütmi) seisukohalt kohustuslik. Rütmiliselt korduvaid ridu võivad moodustada kõik keeleelemendid, sealhulgas ka need, mis tavakõnes iseseisvat tähendust ei kanna ning on vaid keele formaalse (grammatilise) mehhanismi teenistuses. Nii võivad reeglipäraselt korduda kindlad foneemid, morfoloogilised üksused, silpide või rõhkude arv, intonatsioonilised figuurid, süntaktilised konst-

1 Käesolev tekst pärineb Juri Lotmani arhiivist (Eesti Semiootikavaramus) ning on kirjutatud 1980. aastate teisel poolel „Noore kirjandusuurija entsüklopeedilise sõnastiku“ („Энциклопедический словарь юного литературоведа“) jaoks, kus see ka 1988. aastal ilmus pealkirja all „Luule ja proosa“ („Поэзия и проза“), ning on levinud internetis anonüümse väljaandena. Lotmani bibliograafiad seda kirjutist ei esita. Tõlkija on tänulik Silvi Saluperele paranduste ja nõuannete eest ning abi eest teksti ilmumisandmete tuvastamisel.

2 Siin on peetud silmas üht kuuest Roman Jakobsoni kommunikatsioonimudeli funktsioonist (Jakobson, Roman 1960. Closing statements: Linguistics and Poetics. - Style in Language. Ed. Th. A. Sebeok. Cambridge, MS: MIT Press, pp. 350-377; eesti keeles Jakobson, Roman 2012. Lingvistika ja poeetika. TIk N. Lopp, A. Merilai. Akadeemia, nr 10, Ik 1731-1773). Poeetilise funktsiooni fookus on eelkõige sõnumil endal ning see on sõnakunsti keskne funktsioon, piirdumata üksnes luulevaldkonnaga, vaid toimides kõigis keelelistes tegevustes toetava koostisosana. 
ruktsioonid või kivistunud valmisfraseologismid. Ehkki sagedamini koonduvad värsis paljud korrastussüsteemid, hakkavad mõned neist mängima domineerivat rolli, muutudes tunnuseks, mille järgi mingi kultuuri raames eristatakse värsse mittevärsilisest kõnest. Nii moodustub anafooriliste (sõna alguses paiknevate) foneemide korduvuse teel allitereeriv värss, mis on iseloomulik vanagermaani, skandinaavia ja vanaeesti poeetilistele traditsioonidele, pikkade ja lühikeste silpide korrastatus oli iseloomulik antiiksele (vanakreeka ja vanaladina) värsile, sama silbiarvuga üksuste kordamises seisneb silbiline värss (prantsuse, poola, itaalia), sama arvuga rõhkude kordamises aga rõhuline värss (nt Majakovski värss), rõhutute ja rõhuliste silpide vaheldumises silbilis-rõhuline värss (nt Lomonossovi rajatud vene värsisüsteem³), intonatsiooni korrastatuses hiina värss, süntaktilises parallelismis piibellik värss. Morfoloogiliste elementide kordused viisid riimi tekkimiseni.

Tekstisiseste, keeleliste korrastatuste võit täiendavate ja väliste (muusikaliste, žestiliste jt) üle, mis ajalooliselt taandusid tahaplaanile, on seotud terve rea asjaoludega: kirjakultuuri ja trükikunsti areng, luule ja tervikuna kultuuri individualiseerumine jm. Tähtsaimat rolli mängis aga see, et keeles vahetult tähendusega mitteseotud elementide muutumine korrastatuks ja seega tähendusega laetuks tõstis järsult teksti informatiivsust. Tekkis üllatav nähtus: poeetiline tekst, mis koosnes samadest sõnadest jt keeleelementidest kui mittepoeetiline tekst, osutus rikkama sisu kandjaks, värsistruktuuri lagunemise korral see sisu aga laguneb (nt värssteksti proosavormis ümberjutustuses). Värss on mittevärsist sisukam. See ilmneb muuhulgas selles, et kõige tähendusrikkama luuleteksti maht (sõnade arvult) on proosatekstiga võrreldes oluliselt väiksem. Ilmneb, et värsistruktuur on võimeline mitte ainult s äili t ama kindlat informatsiooni (täitma mnemoonilist funktsiooni), vaid ka genereerima tähendusi, to otma informatsio oni. Seetõttu, pärast kirjakultuuri tulekut, kui kultuurimälu jaoks tekkisid võimsad lisavahendid, ei surnud keele poeetilist funktsiooni realiseeriv värss välja, vaid muutus sõnakunsti elemendiks, uue informatsiooni generaatoriks ja kollektiivse teadvuse (kultuuri) relvaks.

Keeleliste seoste küllus ja mitmekesisus iga teksti sees viib selleni, et informatsiooni vastuvõtja võib näha tähenduslikke seoseid (s.t võtta teksti esteetiliselt vastu) seal, kus sõnumi saatja seda ei eeldanud. Nii näiteks rääkis Lev Tolstoi, et värss on eriliselt ilus arusaadavas, ent mitte emakeeles. Keele poeetiline funktsioon on olemas igas kõneaktis, värsistruktuur toob selle esile ja muudab lugejale tajutavaks. Seetõttu piisab püsiva ja arenenud poeetilise traditsiooniga kultuurides selleks, et üks või teine tekst võiks täita keele poeetilist funktsiooni, üksnes teatud signaalist, mis lubaks auditooriumil selle vastu võtta värsina. Nii näiteks võivad sellisteks signaalideks olla graafika, teksti jagunemine stroofideks,

3 Mihhail Lomonossov võttis 1739. aastal vene luule jaoks üle Martin Opitzi 1624. aastal saksa luulekunstile välja pakutud põhimõtted, mis lähtusid sellest, et saksakeelse luule jaoks on sobivaim mitte välteline ega silbiline, vaid rõhuliste ja rõhutute silpide kontrastil põhinev värsisüsteem. 
„riimi märgukellad“ (Ahmatova ${ }^{4}$ ). Vanavene kultuuris tajuti riimi, vastupidi, proosa ja hiljem kõnevärsi traditsiooni tunnusena. ${ }^{5}$ Seda rolli võivad täita ka teksti lülitamine luulekogumikku ning žanriline alapealkiri „värsid“. Vers libre - vabavärss - aga põhineb värsi tekstisiseste struktuursete tunnuste viimisel miinimumini ning keskme ülekandmisel auditooriumi assotsiatsioonidele.

Sõna proosa kasutatakse kahes tähenduses:

1) proosa kui mittekunstiline, argine kõne, mis vastandub kõigile sõnakunsti liikidele;

2) proosa kui kunstiline proosakõne, mis vastandub kunstilisele poeetilisele kõnele.

Esimesel juhul tähistab proosa kõnet, mis on tekstiülesel tasandil organiseerimata ning reguleeritud üksnes keelestruktuuri normidega. Teisel juhul peetakse proosa all silmas kõnet, mis on kunstiliselt organiseeritud, ent seda teiste seaduste järgi kui värss. Sellisel juhul esinevad värss ja proosa kahe kõnesfäärina, mis teineteist vastastikku organiseerivad. Kui ajalooliselt on värsskõne võimalik vaid vastassuhtes argiproosaga sellele vastanduva kõnetegevuse sfäärina, siis proosa kui kunstiline fakt tekib värsikultuuri järel ja selle taustal. Perioodidel, kui luule ja kunstiline proosa arenevad üksteisest eemale tõukudes, avaldub nende funktsionaalne komplementaarsus (vrd Puškini kaebust: „Meil kasutatakse proosat nagu värsistust" $\left.{ }^{*}\right)$. Kunstilise proosa struktuuris domineerivad sellisel juhul miinusvõtted7 (võtete tähenduslik puudumine, mida tajutakse poeetilise struktuuri harjumuspäraste ootuste taustal). Kunstiline proosa imiteerib olmeproosa jooni, võttes sellelt üle individuaalset ebareeglipärasust ja jutustuse eripära („kõneline mask“8, pajatus), dialoogi elliptilisus,

4 Fraas pärineb Anna Ahmatova tsükli „Meisterlikkuse saladused“ („Тайны ремесла“) avaluuletusest „Looming“ („Творчество“): ning juba sõnad kokku kõlasid / ja õhulise riimi märgukellad.

5 Sarnaselt toimis ka homoioteleuton vanakreeka ja rooma kõnekunstis.

6 „Meil kasutatakse proosat nagu värsistust: mitte argivajaduse pärast, mitte vajaliku mõtte väljendamiseks, vaid üksnes vormide meeldiva väljendamise pärast.“ Vrd Aleksandr Puškin, „Materjale kirjade, mõtete ja märkmete katkete juurde" (http://rvb.ru/pushkin/01text/07criticism/02misc/1001.htm).

7 Terminit miinusvõte (минус-приём) kasutab Lotman esimest korda oma 1964. aasta monograafias (Лотман, Юрий Михайлович 1964. Лекции по структуральной поэтике: введение, теория стиха. Тарту), tähistamaks ootuspärase elemendi esteetilistest eesmärkidest lähtuvat ärajättu. Nii võib võtte puudumine olla sama tähendusrikas kui võtte esinemine.

8 Kõneline mask on mingile kirjandustegelasele omane kindel kõnepruuk, mis on esiteks äratuntav ja teiseks eristab teda teistest tegelastest (vrd Лотман, Юрий Михайлович 1979. Речевая маска Слюняя. - Вторичные моделирующие системы. Тарту: Тартуский государственный университет, с. 88-90).

9 Сказ, vene formalistide termin, mille Boriss Eichenbaum on defineerinud järgmiselt: „Pajatuse all pean ma silmas sellist jutustava proosa vormi, mis oma leksikas, süntaksis ja intonatsiooni valikus järgib orientatsiooni jutustaja suulisele kõnele, sisaldades oraatorlikule kõnele või poeetilisele proosale orienteeritud vorme“ (Эйхенбаум, Борис Михайлович 1925. Лесков и современная проза. - Литература: Теория, критика, полемика. Ленинград: Прибой; eesti keeles Märt Väljataga tõlkes kogumikus Väljataga, Märt (koost.) 2014. Kirjandus kui selline. Valik 
kõnekeelsus, orienteeritus suulistele vormidele (vrd „Romaan nõuab lobisemist“, Puškin ${ }^{10}$ ). Nende kunstilise kõne kahe valdkonna lähenemisperioodidel võib kunstiline proosa omandada värsi jooned: häälikulise organiseerituse, kõrgendatud rütmilisuse, intonatsioonilise korrastatuse jne (vrd Karamzini ${ }^{11}$, Andrei Belõi ${ }^{12}$ jutustusi, M. Kuzmini ${ }^{13}$ proosat, Serapionide ${ }^{14}$ ornamentaalset proosat 1920. aastatel). Sellise lähenemise tähe all võib tekkida žanride konversioon („Jevgeni Onegin“ kui romaan värssides, „Vaskratsanik“ - Peterburi jutus tus autori määratluse järgi, „Surnud hinged“ - poeem, Turgenevi luuletused proosas). Samaaegselt on võimalik värsi „proosastumine“ (Nekrassov, Majakovski), s.t värssi selliste elementide sisseviimine, mida lugeja tajub proosale omastena ja värsile võõrastena. Värsi ja proosa vahekord kajastab tekstis kunsti ja elu vahekorra kontseptuaalset mitmekesisust.

\section{K i r ja n d u s}

Gaspar ov 1984 = Гаспаров, Михаил Леонович. Очерк истории русского стиха. Метрика. Ритмика. Рифма. Строфика. Москва 1984: Наука, с. 19-50.

Lotm a n 1972 = Лотман, Юрий Михайлович. Анализ поэтического текста: структура стиха : пособие для студентов. Ленинград 1972: Просвещение.

To ma š evs ki 1959 = Томашевский, Борис Викторович. Стилистика и стихосложение: Курс лекции. Ленинград 1959: Гос. учебно-педагогическое изд-во.

Tõlkinud ja kommenteerinud Maria-Kristiina Lotman

vene vormikoolkonna tekste. Tallinn: Tallinna Ülikooli kirjastus, Ik 320).

10 Kirjast Aleksandr Bestuževile (1825), vrd http://rvb.ru/pushkin/01text/10letters/1815 _ 30/01text/1825/1318 _ 135.htm.

11 Nikolai Karamzini proosat iseloomustab rütmiline korrastatus, milles lühikesed rütmilised üksused vaheldusid tugevamate rõhkudega fraasilõppudes.

12 Mitmed Andrei Belõi romaanid on kirjutatud kas läbivalt meetrilises proosas in continuo esituses või metriseeritud proosas, milles on meetriliste üksuste kordumine küll vähem reguleeritud, ent siiski valdav.

13 Mihhail Kuzmin on samuti kirjutanud rütmilist proosat.

14 Vennad Serapionid oli Peterburis 1921. aastal loodud kirjandusrühmitus, mille nimetus oli laenatud Ernst Theodor Amadeus Hoffmanni samanimelisest romaanist („Die Serapionsbrüder“). Rühmituse liikmed olid nt Mihhail Zoštšenko, Venjamin Kaverin, rühmituse manifesti autor Lev Lunts, Konstantin Fedin, Jelizaveta Polonskaja jt. Mitmed rühmitusse kuuluvad kirjanikud lõid ka rütmistatud proosat. 